\title{
Akademin bör premiera sätt att förena humanvetenskapen och naturvetenskapen $i$ att gripa sig an mänsklighetens utmaningar
}

\begin{abstract}
Eftersom de globala utmaningarna måste lösas genom en integrerad kunskap om människor, samhällen och natur, borde akademin tillämpa system som uppmuntrar till flerdisciplinära ansatser som rymmer såväl humanvetenskap som naturvetenskap. Ännu viktigare för akademin än att samla kunskap är att formulera och förstå mänsklighetens problem, till vars lösningar den insamlade kunskapen kan användas.
\end{abstract}

\section{Om silor, fiskfjäll och galaxer}

Akademin har strukturproblem. Den har ofta liknats vid silor. Tänk dig ett batteri betongsilor av den typen som ofta dominerar svenska hamnområden. Jag tillbringade en sommar för många år sedan i Kalmar med att hacka loss foderrester från insidan av stora betongsilor och kan intyga att de är väldigt väl avskilda från varandra. Inuti en akademisk silo är det dock en sjudande aktivitet; alla känner alla och har koll på vad de gör, vem som är bäst, och vem som är i dalande, vem som blivit publicerad i Nature och vem som snyltat på andras resultat. Men de har inte en aning om vad som pågår i grannsilon, än mindre vad som pågår i ett annat silobatteri, som kanske heter humaniora. Och tyvärr uppträder inte världens problem i några silor alls; de är så komplexa och

How to cite this book chapter:

Casson, A 2015 Högskolans ansvar: Principer för utveckling av den högre utbildningen. London: Ubiquity Press. DOI: http://dx.doi.org/10.5334/bap.g License: CC-BY 3.0 
sammansatta att de kräver människor som behärskar innehållet i flera olika silor samtidigt. Och sådana akademiker finns det inte många av. Det akademiska systemet är istället riggat för att direkt avskräcka alla försök till ämnesintegrering och mångvetenskapliga studier, inte minst över de stora gapen mellan humanvetenskap och naturvetenskap.

Silorna har under senare år varit en spridd och omstridd bild av disciplinernas isolering $i$ åtminstone den amerikanska debatten. Eftersom de bilder vi använder för att hjälpa oss tänka ofta är avgörande för hur resonemang förs, finns det anledning att återge ytterligare åtminstone en liknelse. I en uppsats från 1969 som fortfarande ofta citeras när det gäller akademiska discipliners åtskildhet, beskriver den amerikanska socialpsykologen Donald Campbell hur det är och hur det borde vara i två slående bilder. Den ena visar hur discipliner uppträder i etnocentriska kluster utan att kommunicera med varandra och utan att täcka in väsentliga delar av verkligheten. Grupper av ämnen hänger ihop som grodägg, fritt svävande utan kontakt med något annat kluster. Den andra bilden visar hur discipliner genom en överlappning som liknar fiskfäll skulle kunna kommunicera med varandra och samtidigt bli mera heltäckande. Själva titeln på Campbells uppsats, "Ethnocentrism of Disciplines and the Fish-Scale Model of Omniscience", talar om hur han ser på problemet och dess lösning. Varje disciplin utgör alltså ett kluster av forskare och specialiteter, med betydande överlappning och stort utbyte med varandra. De bygger sina relationer väldigt tätt med varandra, inom samma institution, förstås, men också nationellt och i hög grad internationellt genom tidskrifter, lärda samfund, konferenser och så vidare. En sociolog har en betydande kunskap om vad som sker inom sin disciplin i världens mest avlägsna hörn men ingen kunskap alls om vad statsvetaren i nästa korridor sysslar med, än mindre litteraturvetaren på nästa våning. Dessutom finns en tydlig tendens till vad Campbell kallar etnocentrism, att man vänder hela sin uppmärksamhet mot de särskiljande dragen för den egna gruppen. Doktorander förstår att om de ska göra karriär måste de välja avhandlingsämnen och arbetssätt som nära ansluter sig till ämnets centrala traditioner och sina professorers preferenser. Det finns alltså en inbyggd, essentialistisk rörelse mot mitten, istället för ett sökande efter fruktbara kombinationer och jämförelser utanför det egna ämnets gränser. I Sverige har de senaste årens kvalitetsgranskningar samordnade av Universitetskanslersämbetet men genomförda av disciplinernas främsta företrädare visat hur stark denna strävan mot disciplinens innersta kärna är. Ett avgörande kriterium för kvalitet i en students självständiga arbete har genomgående varit hur disciplinens centrala teorier och metoder beskrivits och använts. Bland åtgärderna som högskolorna vidtagit under hot om indragna examensrätter och därmed pengar och jobb, har varit att se till att undervisningen först och främst täcker disciplinens traditionella kärna. Transdisciplinärt nytänkande beivras, akademin stelnar i sina former.

Campbells bild visar att det mellan klustren inte finns några relationer, utan att det finns stora utsnitt av verkligheten omkring oss som aldrig blir 
uppmärksammade. Den idén han för fram är att discipliner bör söka efter att som fiskfäll överlappa med sina omgivande discipliner eller åtminstone se till att det finns möjliga vägar fram emellan dem, även om man förmodligen får korsa många vassa fälllkanter för att komma ända från humaniora till naturvetenskap. Campbells tanke att ämnesspecialister skulle sätta en ära $i$ att läsa tidskrifter och bevista konferenser utanför det egna området är lika tilltalande, men kanske ännu mera otänkbar, än för snart femtio år sedan då artikeln skrevs. ${ }^{108}$

2009 dök det upp en märklig bild som visade att Campbell hade i stort sett haft rätt. Under de decennier som gått sedan artikeln publicerades har hela den digitala informationsrevolutionen ägt rum. Akademiker publicerar sina artiklar och läser sina tidskrifter numera på nätet. Det betyder att man i bästa Google-stil kan kartlägga vanorna hos varje användare och registrera hur läsare flyttar från att läsa en tidskrift till en annan. "The new map of knowledge" kallade New York Times bilden; kartläggningen är utförd av en grupp forskare vid Los Alamos National Laboratory, det stora forskningslaboratoriet i New Mexico där man arbetar bl.a. med design av kärnvapen. Kartläggningen är ny men bilden visar tydliga drag av båda Campbells skisser. Klustren består och förstärks men det finns en del relationer mellan dem i ett fiskfjällsliknande mönster. Där det stora gapet finns i universum är mellan humanvetenskaperna och naturvetenskaperna, något som jag strax ska återvända till. Det enda området där finns en viss sammankoppling tycks vara miljövetenskap. Det ger en gnutta hopp.

Bilden av akademiska discipliner som isolerade silor, utan kontakt med världens egentliga problem är inte oomtvistad. I en ny och gedigen genomgång av den amerikanska debatten och av fakta i målet finner sociologen Jerry A. Jacobs att det snarare är tvärtom, att idéer flödar mellan disciplinerna, att man övertar nya begrepp och statistiska metoder ganska snabbt och att det dessutom är en myt att disciplinära akademiker inte skulle ge sig in i världens dagsproblem. Jacobs ser disciplinerna som ett nödvändigt och fungerande nätverk av specialiseringar, väl avpassade för att främja dynamisk inomvetenskaplig konkurrens. ${ }^{109}$ När det gäller engagemang i samhällsfrågor finns nog

108 "Rather than praying, "May I be a competent and well-read X-ologist, may I keep up with the literature in my field," he [a scholar] will pray, "Make me a novel fish-scale. Let my pattern of inevitably incomplete competence cover areas neglected by others." Each scholar would then try to have a pattern of journal subscriptions unique to his or her department, university, or profession. Noting that the scholar and a colleague were reading the same set of journals, the scholar would feel guilty and vow to drop one of these in favor of some other. Recognizing that the interdisciplinary links in the collaborative web of knowledge are the weakest, the scholar would give up some ingroup journal in favor of an outgroup one. He would feel guilty if he did not cut attendance at ingroup conventions to attend relevant outgroup ones, etc." (Campbell 1969)

109 "The notion of academic disciplines as isolated silos has been debunked. On the contrary, ideas flow quite frequently between fields. Statistical innovations are adopted far and wide as they prove useful; conceptual innovations make their way across frontiers between disciplines... Nor do discipline-based scholars shun the vexing issues of the day. Thousands of researchers 


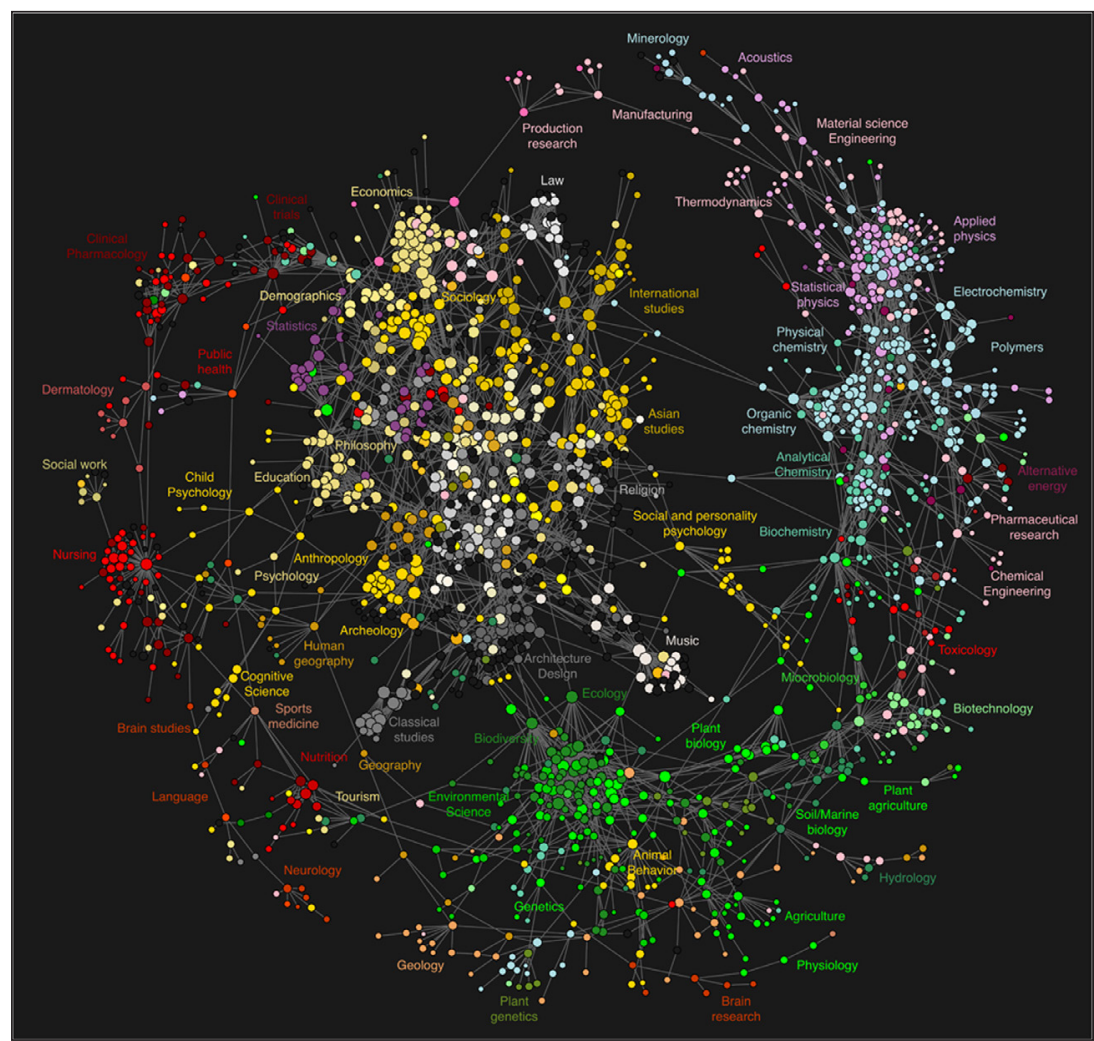

"The New Map of Knowledge." Strecken visar hur läsare av akademiska tidskrifter rör sig från en tidskrift till en annan. Broarna är få mellan de naturvetenskapliga och de humanvetenskapliga klustren. (Bollen et al 2009 http://journals. plos.org/plosone/article?id=10.1371/journal.pone.0004803)

stora skillnader mellan USA och Sverige men om disciplinernas nödvändighet finns inte mycket att invända. Självklart behövs specialisering; utan den får vi ingen fördjupning. Den inomvetenskapliga konkurrensens nackdelar i form av nepotism och konservatism är nog minst lika stora som fördelarna, men jag tycker Jacobs missar det stora problemet, det som syns så tydligt på stjärnkartan över tidskriftsläsandet: gapet mellan humanvetenskap och naturvetenskap som uttrycks i en brist på intresse och kanske ibland bristande respekt för varandra. Jag ska strax ägna lite utrymme åt att försöka förstå hur det kommer sig att det är så. 
Mängden information som vi har tillgång till spelar förstås också en roll för en fortsatt balkanisering av discipliner. Informationsmängden bidrar troligen också till vår upplevelse av att vi har för lite tid och för små möjligheter att ens försöka börja överbrygga gapen. I en intervju jag såg nyligen med Zygmunt Bauman, är det första han vill säga om kunskap att den just är så extremt uppdelad. Folk på den ena våningen i en universitetsbyggnad läser aldrig vad som skrivs av dem på nästa våning. Kunskapen utvecklas på ett sådant sätt, säger han, så att vi kommer att veta allt om inget. Ditt expertområde smalnar av hela tiden, medan mängden kunskap som finns inom området växer. Dessa motsatta trender gör att det blir allt svårare att överblicka vad människan vet. Han påminner om att i antikens Grekland, där de första pedagogerna var upphöjt omedvetna, gracefully unaware, om hur mycket kunskap ännu fanns kvar att upptäcka, gick det att lära sig allt man behövde veta under bara ett eller ett par år av sitt liv. Idag finns oändligt mycket information på nätet men eftersom det mesta är irrelevant och obrukbar blir den grundläggande kunskapsförmågan att kunna skilja agnarna från vetet, säger Bauman. I en slående jämförelse, som man i och för sig undrar hur han belägger, hävdar han att det finns mer information i en enda söndagsupplaga av New York Times än renässansens mest intelligenta människa kunde tillgodogöra sig under en hel livstid. Och, som han säger, vi har många söndagar i vårt liv - så om man läser NYT har man problem. ${ }^{110}$

Men flervetenskapliga ansatser i forskningen räcker knappast för att formulera mänsklighetens problem och finna möjliga handlingsvägar i världens utveckling. Det finns ett grundläggande problem också i akademikernas ovilja och olust att uttala sig om sådant som man inte till fullo behärskar - det är det som folket på nästa våning behärskar. Man kan med förbehåll och ursäkter möjligen uttala sig om sitt eget område som man ägnat decennier åt men att uttala sig om något annat område är opassande övermod. Det är det vetenskapliga umgängets regel nummer ett att vänta med att berätta om hur något förhåller sig till dess att experimentet upprepats flera gånger och resultaten utsatts för en rigorös prövning genom peer review - och även då omgärda ett uttalande med en rad förbehåll. Det är politikernas sak att tvärsäkert säga sådant som de tror, vetenskapsmannen håller tand för tunga tills han är säker. Men har inte den som rigoröst och länge fördjupat sig i ett område utvecklat en uppsättning förmågor, ett omdöme, som gör att hon borde med viss auktoritet utifrån sitt område kunna uttala sig om den helhet i vilken området utgör en del? Så gör vi inom ett ämne eller en disciplin, där forskare som fördjupat sig i den ena typen av molekyl, bedömer forskning som berör en helt annan typ av molekyl. Man har problem och metoder gemensamt, man kan bedöma forskningens upplägg och stringens, hållbarheten i tolkningen av resultat. Från specialiseringstrattens smalaste, djupaste del, bör man ändå ha en god utblick upp genom dess

${ }^{110}$ http://www.ur.se/Produkter/176736-Larandets-idehistoria-Vad-ar-kunskap\#related-page=1 2013-11-27 
öppning mot hela världen. Således är fysikern väl rustad att uttala sig, inte bara om den enskilda atomen utan om kärnfysiken, om kärnkraften och energipolitiken och klimatförändringar och även om politikens tydliga oförmåga att hantera problemen. Inte nog med att hon är rustad, hon är också skyldig sitt samhälle att delge sin syn och inte gömma sig, längst ner i sin tratt, bakom sin akademiskt klädsamma ödmjukhet.

Naturvetenskapen har, kanske delvis på grund av det allmänt hyllade och svårersättliga peer-review-systemet, i sina vetenskapliga artiklar länge varit tämligen obegriplig för utomstående. Tillgänglighet för utomstående har inte varit viktig och de utomstående, i sin tur, har inte varit särskilt intresserade, såvida inte rönen gällt en ny risk, i synnerhet en hälsorisk eller ett botemedel. Man skriver för sina gelikar och för sina professorer, för tidskrifternas artikelgranskare och redaktörer. Man skriver i tro att man bäst bidrar till forskningens kvalitet och därmed till mänsklighetens väl, genom att anpassa sig till en inomvetenskaplig mall och ett inomvetenskapligt språk, som snart kan bli tämligen obegripligt för alla utom de invigda. Och detta är förstås nödvändigt, om man ska komma framåt någorlunda raskt och inte behöva återvända till ursprungspremisser i varenda artikel. På samma sätt som matematiken var tvungen att uppfinna en slags avancerad stenografi för att kort och entydigt uttrycka vissa storheter och relationer, så måste varje forskningsgren utveckla sitt språk och uppsättning av givna begrepp och relationer. Men det är inte bara så att systemet uppmuntrar detta: systemet sätter effektivt stopp för allt annat. Det finns ju en kader skickliga vetenskapsjournalister, tänker man kanske, och forskarna själva behöver inte bemöda sig om att nå ut till en bredare publik; åtminstone finns det inga incitament i karriärstrukturer eller inomfacklig status i att skriva begripligt för en bredare publik. Det är fler än en erkänd naturvetare som menar att till och med de mest komplexa och sofistikerade vetenskaplig sammanhang går att förklara med ett vanligt språk utan att förenkla eller förhindra en djupare förståelse. ${ }^{111}$ Och här är humanister och samhällsvetare minst lika goda kålsupare som naturvetare och teknologer, förstås, med intrikata teoribildningar och inåtblickande avhandlingar fyllda av blinkningar och bugningar åt den egna klanens hjältar.

Det finns åtminstone gott om försök att popularisera naturvetenskapen, men det är sämre ställt med tidskrifter och tidningsartiklar som tillgängliggör komplexa samhällsanalyser. Och ändå bildar Bourdieus maktteorier, Foucaults genomlysning av modernitetens institutioner, Eliades insikter om tro och religion, för att nämna några namnkunniga storheter, välbehövliga verktyg för den som vill begripa sin samtid och påverka sin framtid. Jag nämnde en gång för en

111 Det är den amerikanska paleontologen och idéhistorikern Stephen Jay Gould jag hänvisar till här: "I believe - and have attempted to put into practice in some fifteen books of general writing - that even the most complex and sophisticated scientific concepts can be explained in fully accessible layman's language without any dumbing down, or loss of the detail and technical concepts required for genuine understanding." (Gould 2002, s 140) 
framstående litteraturteoretiker, tillika medlem i Svenska akademien, att mina studenter tyckte att hans texter var svårförståeliga och att de undrade om det inte gick att få fram budskapet på ett enklare sätt. Han svarade att det inte går att återge komplexa och nyanserade resonemang utan ett komplext och nyanserat språk. Och det accepterar jag, inte minst inom sådana områden där själva språket utgör, så att säga, sitt eget studieobjekt. Men jag vill trots allt hävda att det inom alla fält finns de skribenter som är måna om att läsarna, var de än kommer ifrån, kan följa med i komplexa och nyanserade resonemang, och de som är mera måna om att imponera på kollegorna. Systemen för akademisk publicering bör i högre grad uppmuntra de förra och beivra de senare.

I den mån det faktiskt finns sådana både seriösa och tillgängliga presentationer av humanvetenskaplig forskning, läses de knappast av teknologer och naturvetare, vars självbild snarare bygger på ett avståndstagande från sådana mångordiga teoribyggen, fjärran som dessa är från hårddata och objektiv tillförlitlighet. Undantag finns, återigen, men inte så många att det märks.

Lundafilosofen Hans Larsson skrev för drygt ett sekel sedan en essä med titeln Om bildning och självstudier (1908) där undertiteln är talande för hans budskap: "Icke allt, men det hela - i delen". Man kan inte lära sig om allt, skriver han, det vilar något patetiskt över dem som försöker, utan man bör ägna sig åt "den koncentration som för en på djupet och därigenom till det personligt bildande, till det centrum där de olika fackens frågor får sin enhet." ${ }^{\prime 12}$ Han uppmanar till exempel läsaren att inte ägna sig åt "slappläsning av reseskildringar" utan att fördjupa sig ordentligt i ett enda land. Som av en händelse nämner han Japan, som han genom Nordenskölds berättelser fått veta är ett föredöme i hyfs och snygghet. En sådan verklig fördjupning "skall ge er en känsla av trevnad att ha en dylik specialitet, och det skall visa sig att det icke blott är Japan ni studerat utan mänskligheten."113 Och detta är naturligtvis också hela högskoleutbildningens och forskningens idé - en allt smalare specialisering som tillåter forskaren att borra så djupt det går och med största möjliga säkerhet och sanningsanspråk lägga sin lilla bit i det stora kunskapspusslet. Problemet uppstår när hon inte vänder om från sin djupborrning för att se - och uttala sig om - helheten, inte bara inom sin disciplin men i den värld där hon lever.

\section{Om gapet mellan två kulturer}

Högskolan bör alltså i sin forskning och utbildning främja en allsidig belysning av människan, naturen och samhället genom användning av såväl naturvetenskapens som humanvetenskapens ansatser, hävdar jag i denna princip. Men det verkar så gott som omöjligt att få de två kulturerna att ta sig an varandra, att respektera och använda varandras metoder och perspektiv. Redan 1959 höll

112 Hans Larsson i Burman (red) 2010, s 190.

113 Ibid, s 189. 
den engelska kemisten och författaren C.P. Snow (1905-1980) ett offentligt föredrag i Cambridge med titeln The Two Cultures och ett sådant djupt intryck gjorde han att man fortfarande hänvisar till den över hela världen, så snart frågan om gapet mellan humanvetenskaper och naturvetenskaper kommer på tal.

Om man läser Snows tal idag, blir vissa framträdande drag bland intellektuella i 1950-talets England väldigt tydliga: den naturvetenskapliga optimismen och förvissningen om att nya upptäckter kommer att rädda världen (detta under det kalla krigets värsta rädsloår); respekten för Sovjet och inte minst den tekniska och naturvetenskapliga utbildningen där; respekten för författare och litteraturkritiker i England, inte bara som offentliga smakdomare utan också som tongivande samhällskritiker; framförallt insikten om att gapet mellan fattiga och rika i världen inte får och inte kan bestå. Att tala om detta sista var för övrigt minst lika viktigt för Snow som de två kulturerna och han berättar att han hade funderat på att kalla föredraget The Rich and the Poor istället. Den delen av hans tal har dock inte gått till eftervärlden. Istället är det den grundläggande och ömsesidiga oförmågan hos naturvetare/tekniker och samhällsvetare/ humanister att tala med varandra, att över huvud taget förstå varandras språk, som under de femtio åren som förflutit, ständigt dyker upp i debatten. En av de viktigaste orsakerna hittar Snow i den engelska skolans tidiga ämnesspecialisering, som han kontrasterar med USAs och Tysklands starkare betoning av naturvetenskap i skolan. Det leder till ett elände som jag själv fătt uppleva: jag fick välja bort kemi som ämne som tolvåring därför att jag ville läsa tyska. I min engelska grammar school läste jag mellan 16 och 18 år enbart tre språk och deras litteratur, inga andra ämnen alls utom idrott. Att läget i England inte blivit så mycket bättre sedan dess vittnar en kommentar i The Guardian. Det är en brittisk högskolestudent i språkämnen som berättar hur den tidiga uppdelningen i naturvetenskapliga respektive hum-sam-studier fördärvar språkförmågan på båda sidorna: "Det stora flertalet NT-studenter i detta land slutar helt enkelt att skriva allt som är längre än ett Facebook-meddelande när de fyller 16 och tappar därför sin skrivförmåga, på samma sätt som en humsam-student få gå igenom livet med matte-kunskaper på en 12-årings nivå’. ${ }^{114}$ Det svenska gymnasiet är, som väl är, något mera balanserat, men andelen elever som får ett livslångt intresse för och grundläggande självkänsla i naturvetenskapliga och matematiska spörsmål verkar sjunka år efter år. Och det är knappast så enkelt som att vi kan ändra på skolans läroplan och därmed upphäva gapet mellan humanvetare och naturvetare.

Motsättningen mellan humanvetenskaperna och naturvetenskaperna tycks ha uppstått relativt sent i västvärldens intellektuella kulturhistoria. Den

\footnotetext{
114 "The great majority of science students in this country simply cease to write anything longer than a Facebook message once they hit 16, and consequently lose their writing skills in the same way that humanities students end up with the numeracy of a twelve year old." (http://www. theguardian.com/higher-education-network/blog/2014/mar/19/humanities-universitiesglobal-stem 2014-03-19)
} 
moderna naturvetenskapen uppkom ju först under 1600-talet med dess anspråk på att finna kunskap som är oberoende av människan och som kan uttryckas i eviga naturlagar. Under upplysningen kunde en individ dock fortfarande göra anspråk på encyklopedisk kunskap och bli tagen på allvar. Kunskaperna sågs fortfarande som sammanhängande, som en del av ett enda system av mänskligt vetande om naturen, människan och hennes samhällen. En fysiker under upplysningen kunde inte med heder förklara sig okunnig om Aristoteles eller Dante, lika lite som en humanist kunde frånsvära sig kunskap om naturlagarna. Linné, för att ta ett svenskt exempel, var en stor humanist och hans naturstudier utgjorde i grunden ett livslångt samhällsvetenskapligt projekt: han ville visa hur Sverige kunde förädla sina naturtillgångar för att utveckla rikets ekonomi. Tebuskar och bananplantor skulle odlas i Uppsala och falkenerarens färdigheter läras in av norra Dalarnas masar så att de själva kunde exportera de eftertraktade jaktfalkarna till södra Europa och Mellanöstern. Projekten verkar onekligen lätt tossiga och det är kanske inte så konstigt att hans eftermäle enbart grundas på den systematiska namngivningen. Poängen är dock att i mitten av 1700-talet var Sveriges genom tiderna mest namnkunniga naturvetare egentligen upptagen av ett stort samhällsprojekt. ${ }^{115}$ Det verkar vara först under 1800talet, och främst dess senare del, som tudelningen mellan humanvetenskaperna och naturvetenskaperna blir alltmer uppenbar och accepterad. Nya identiteter som naturvetare etableras och humanistfacket begränsas för att utesluta kunskap om människans fysiska uppbyggnad och omgivning. I den engelskspråkiga världen koloniserade naturvetenskapen till och med hela vetenskapen: är det inte naturvetenskap så är det inte science. Litteraturvetenskap, konstvetenskap och de historiska vetenskaperna har ingenting med science att göra i den engelska språkvärlden. Och en av huvudanledningarna måste rimligen ha varit själva mängden kunskap som vuxit snarare logaritmiskt än linjärt. Renässansmänniskan var ju allkunnig - men så hade han heller inte New York Times att plöja om söndagarna.

En av dessa renässansmänniskor, och den som kanske utövat starkast inflytande på eftervärlden genom att vara så utomordentligt mänsklig och läsvärd att människor fortsatt att läsa och njuta av hans tankar i snart ett halvt millenium, var den franske essäisten Michel de Montaigne. Montaigne valde på 1570-talet bort det offentliga livet och stängde in sig i sitt runda torn i Bordeaux med sitt för tiden imponerande bibliotek om tusentalet volymer, mestadels

115 Se Lisbet Koerner Linnaeus. Nature and Nation (1999) där hela bakgrunden till Linnés stora samhällsprojekt tecknas, inte minst försöken att odla exotiska nyttoväxter i Sverige i stället för att importera dem för dyra pengar. Tankarna kring export av jaktfalkar finns i Linnés Dalaresa, som han företog redan 1734, som 27-åring, för att på landshövdingens begäran undersöka vilka rikedomar landskapet Dalarna kunde förädla för rikets väl. För beskrivningen av falkfångsten, se Linnaeus 2007, s 156-160: "Undransvärt är, att falkeneraren, som är holländare eller fransos, reser så lång väg hit, vinner ock härigenom stora pengar. Men däremot ingen svensk, som är i landet, kan lära att taga och upptukta dessa, varigenom våra kunde vinna de penningar." (ibid, s 159) 
antikens tänkare och diktare, för att med skriftens hjälp begrunda sig själv, sitt liv och det samhälle han lever i. Som nutida läsare av Montaignes "försök" blir man tagen av hans oblyga och ständigt nyfikna sätt att borra i sitt eget liv och återge episoder och reflektioner kring dem. Han söker en sanning utifrån sig själv men gör inga anspråk på att nå fram till Sanningen. Han är en skeptiker i betydelsen att han är skeptisk till att det går att nå fram till någon universell sanning eller allmängiltig förklaring av människan och världen. Det finns inga sanningar som inte är rotade i erfarenheter, i tid och plats och människa. Man kan inte vara helt säker på någonting och vår bild av världen är just vår, det vill säga rotad i varje individuell människas upplevelse av den, i hennes fysiska kropp, i en bestämd tid och på en bestämd plats. "När jag leker med min katta - vem vet om inte hon kanske leker mer med mig än jag med henne?"116 frågar Montaigne och ler åt högmodet och inbilskheten hos människan som tror att hon vet så mycket. Samtidigt avslöjar han en ödmjuk undran inför världen. Och om man inte kan vara helt och fullt säker på en enda sak, då kan man inte vara säker på någonting alls. Vi lär oss av våra erfarenheter och andra lär sig av sina, av nöden delvis annorlunda, erfarenheter. Därför bär en sådan hållning med sig en grund för tolerans, för oliktänkande, för en mångfald av hållningar. Montaigne, med all hans varma humanism, hans nyfikenhet och tolerans, var i filosofins termer alltså inte bara skeptiker utan också pluralist. Vi är ändå människor och människor kan inte veta allt, kommer aldrig att veta allt, och därför får vi acceptera att andra människor med andra utgångspunkter kommer att ha andra övertygelser och syn på världen.

Men sedan fanns åtminstone en läsare av Montaignes ord, kanske femtio år efter att de först publicerats, som föresatte sig att hitta den enda saken som man kunde vara säker på: René Descartes hette han och det han kunde vara säker på var att han tänkte. Cogito ergo sum, jag tänker och därför måste jag finnas. Det var han säker på. Vad som följer av en sådan tvärsäker grund för människans vetande är att omständigheterna för kunskapen, dess kontext, dess grund och förklaring i tid och rum och den enskilda människan, minskar i betydelse. Den enskilda människans omständigheter blir till och med en fiende i jakten på den universella sanningen och de universella lagarna som styr människan och hennes värld. Man måste gå från det subjektiva till det objektiva. Under hela 1600-talets naturvetenskapliga revolution med Galileo i början på seklet och Newton på slutet flyttades uppmärksamheten och målet för vetandet från det enskilda i dess unika sammanhang till det allmängiltiga, från det partikulära till det generella. Och det är just den här tron på att människan kan veta allt som ligger bakom det rationalitetens segertåg som kallas den moderna eran eller moderniteten. Och trots decenniers försök av akademins humanister och samhällsvetare att utropa modernitetens död, är det fortfarande modernitetens framtidstro och teknikoptimism som styr det allmänna idéklimatet i västvärlden.

116 Montaigne 2012, s 166. 
Jag försöker, som ni märker, förstå varför och hur akademin blev uppdelad i dessa två läger: inte så mycket krigshärar som utkämpar en strid om det rätta sättet att förstå och tolka människan och världen, utan snarare två världar som lever fredligt med varandra men med extremt lite intresse för varandras frågor och resultat. Det är inte krig i sandlådan utan snarare det lugn som råder när två tre-åringar leker bredvid varandra, till synes knappt medvetna om varandras existens, i egna världar helt egna mål för sin lek.

Från ett annat perspektiv ser paleontologen och idéhistorikern Stephen Jay Gould en del av ursprunget till konflikten mellan naturvetenskap och humanvetenskap i ett krig om makten, en markstrid som de tidiga naturvetarna på 1600-talet behövde ställa till med för att vinna mark från de då fullkomligt förhärskande humanisterna. Humanisterna kunde vila tryggt i sin förvissning om att allt människan behövde veta, visste redan de antika källorna. Om man kunde sin Euklides och Aristoteles, sin Ovidius och Cicero, kunde man allt som var värt att veta. Att försätta en sådan grundmurad förvissning var förstås inte lätt och krävde en konfliktbenägen utmaning. Ett tungt vapen i kriget var, till exempel, något som vi idag tar för givet och självklart: fakta. När renässansens naturvetare skulle sammanställa en beskrivning av naturen, gjorde de som Gesner gjorde i sin Historia animalium, Djurens historia, från 1551, nämligen samlade allt mänskligheten hade någonsin sagt eller vetat om en viss djurart. Som i alla andra sammanhang var det de antika klassikerna som var Gesners främsta kunskapskälla. Han skilde inte mellan verifierbar sanning och skröna, mellan fakta och legend, helt enkelt därför att han inte förstod att en sådan skillnad skulle vara viktig. ${ }^{117}$ Han såg sin uppgift som att dokumentera det vetandet som redan fanns; den nya naturvetenskapens revolution låg $\mathrm{i}$ att det för första gången blev centralt och avgörande att på verifierbara grunder forska fram det nya, hittills obekanta sanningen och därmed slå fast fakta. Det kan verka märkligt för oss nutida människor att fakta skulle vara ett relativt sent påfund. Men den amerikanska litteraturprofessorn Mary Poovey visar med stor säkerhet i sin omfattande A History of the Modern Fact att vad som är ett faktum växte fram som först ur den dubbla italienska bokföringen på 1400- och 1500-talen i Europa. Genom ett sinnrikt system av tre olika böcker kunde man i siffror säkerställa hur skulder, lån och värden förhöll sig till varandra och hålla reda på kredit och debet i siffror, i fakta som kunde verifieras genom ren logisk induktion. Alltsedan dess har siffran och statistiken haft en upphöjd status som oavvisliga fakta framför andra. ${ }^{118}$

För att kunna hävda sin rätt till oavvislig sanning var vetenskapen naturligtvis tvungen att ta en match med kyrkan och den bokstavliga tron på skapelseberättelsen. Den här diskussionen fortsätter än i våra dagar, då fundamentalister av flera slag bekänner sin blinda tro till skriftens sanning, utan hänsyn till vare sig vetenskaplig fakta eller bevis. Gould visar dock att kyrkan inte alltid

117 Gould 2002, s 37 f.

118 Poovey 1998. 
varit så avvisande som man kunde tro till den nya naturvetenskapen. Inte ens Galileo, i den mest kända av alla konflikter mellan kyrkan och vetenskapen, var egentligen särskilt utsatt, menar Gould. ${ }^{119}$ Hade Galileo bara kunnat undvika att förlöjliga den geocentriska världsbilden och presenterat sin tes, att det var jorden som snurrade runt solen och inte tvärtom, på ett mera diplomatiskt sätt hade den kunnat införlivas i den kristna tron. Vilket naturligtvis skedde så småningom, liksom med all andra naturvetenskapliga upptäckter. Även om Darwin och människans evolutionära ursprung varit svårt för kyrkan att svälja, har det gått. Och liksom kyrkan med tiden kunnat anpassa sina läror efter naturvetenskapens upptäckter, har många forskare kunnat förena en gudstro med sina vetenskapliga krav på objektiv sanning. Vetenskapen, påpekar Gould, genom att den just utgörs av ett sökande efter en faktagrundad förståelse, kan inte föreskriva någon som helst moralisk lösning. Den spelar helt enkelt på en annan plan och därför kan den heller inte i sig vara omoralisk, icke-religiös eller okänslig för estetiska hänsyn. ${ }^{120}$

Det finns flera skäl till att vi fortfarande är drabbade av humanvetenskapens och naturvetenskapens oförmåga att mötas. Naturvetenskapen var som sagt tvungen att tidigt ta en kamp med världsföreställningar som byggde antingen på religiös tro eller på grekisk-romersk humanistisk tradition; det är den kampen som i total onödan fortsatt in i våra dagar, åtminstone $i$ en tyst pakt att ignorera varandra. Men förutom detta finns också vad Gould kallar dikotomins dynasti. Med det menar han "vår beklagliga vana att beskriva komplexa sammanhang i termer av oförenliga motsatspar". ${ }^{121}$ Vi har en medfödd oförmåga att se världen i annat än motsatspar, antingen A eller B. Det har gjort att vi ser oss själva och de andra som fotbollslag ser varandra: Vi måste spela för antingen Chelsea eller Man U, vi kan inte ränna omkring på plan och passa bollen lite hipp som happ, beroende på hur situationen är just då. I en fotbollsmatch finns det två mål, inte ett, vilket komplicerar livet ännu mera i en akademi som tycks ha tagit idrottstävlingen som själva sinnebilden för hur vi ska nå framgång i forskningens ligatabell.

Ytterligare en metafor för den splittrande dikotomiseringen ger pedagogikprofessorn Tony Becher i sin klassiska skildring av den brittiska akademin. Academic Tribes and Territories ${ }^{122}$ kallar han boken och även om han visar en betydligt mer intrikat karta med ibland knappt skönjbara gränser och betydligt flera broar mellan lägren än som framgått här, är grunddraget i hans analys tämligen klart: akademins discipliner kan liknas med självförsörjande klaner

\footnotetext{
119 Gould 2002, s 88.

120 "Science by its very nature as a quest for factual understanding and explanation, cannot prescribe a moral resolution to any problem" Gould 2002 s 140. "..the common, yet utterly false, inference that science itself, by its very nature, must be irreligious, immoral, or inherently opposed to aesthetic urges and sensibilities." Gould 2002, s 141.

121 "our lamentable tendency to taxonomize complex situations as dichotomies of conflicting opposites" Ibid, s 112.

122 Becher 2001.
} 
med egna markanspråk. När han kartlägger den fortsatta balkanisering av discipliner som sker allteftersom kunskapsmängden växer, visar han också hur nya discipliner kan uppstå ur transdisciplinärt samarbete. Det har ju också varit högsta mode bland forskningsfinansiärer nu i decennier att uppmuntra tvär- eller mångdisciplinära forskningsprojekt. Den bakomliggande föreställningen har varit att kunskap och innovationer som kan gagna landets ekonomi, vare sig landet heter USA, UK eller Sverige, måste bygga på integrerad forskning som tar sig an ett utsnitt av verkligheten, så som verkligheten uppträder i världen ("i verkligheten", höll jag på att skriva) utanför akademin, i produktionens och konsumtionens värld. Men sådan forskning har sällan på allvar och hos samma forskare integrerat naturvetenskapens anspråk på objektiva sanningar å ena sidan med å andra sidan humanvetenskapens problematisering av människans världsbilder, även så kallade objektiva sanningar och fakta, som sociala och kulturella konstruktioner.

\section{Om ögat bakom kameran}

Det finns alltid en forskare som uttalar sig, ett jag situerat i tid och rum, inbäddad i ett samhälle och indränkt i en kultur. Det finns alltid en människa bakom kameraögat. Det går inte att gömma henne bakom formelartad prosa och forskningsrapportens trogna tjänare, passivformen: "experimentet genomfördes genom att vätskan blandades..." Någon har genomfört experimentet och någon har blandat vätskan, någon som vill någonting, medvetet eller omedvetet. "Hur märkligt är det inte", skriver själva Charles Darwin på ett ställe, "att någon inte skulle inse att alla iakttagelser måste vara för eller emot en åsikt om det ska vara till någon nytta." 123 Samma insikt finns naturligtvis hos många kloka forskare också idag, men att redovisa sina åsikter utgör knappast den bästa förutsättningen för att få en artikel publicerad. Forskaren förutsätts inte ha några åsikter, eller åtminstone inte sådana åsikter som kan påverka utgången av ett objektivt experiment eller en oberoende undersökning. Ändå vet både forskarens meningsfränder och hennes motståndare att det är just en viss bild av ett visst utsnitt av världen som hon bygger upp genom att välja att visst experiment eller en viss undersökning.

Den orubbliga och oproblematiserade tron på objektiviteten reser alltså en av de svårforcerade murarna mellan naturvetenskapen och humanvetenskapen. En annan mur består av den så kallade reduktionismen. Reduktionism innebär att man kan reducera varje problem till dess allt mindre beståndsdelar

${ }^{123}$ I ett brev från Darwin till en kollega, Henry Fawcett, 18 september, 1861 "About thirty years ago there was much talk that geologists ought only to observe and not theorise, and I well remember some one saying that at this rate a man might as well go into a gravel-pit and count the pebbles and describe the colours. How odd it is that anyone should not see that all observation must be for or against some view if it is to be of any service!" (min kurs.) http://www. darwinproject.ac.uk/letter/entry-3257, 2014-05-05 
och genom att bryta ned det kan man bättre förstå och därmed också så småningom lösa problemet. Naturvetenskapen har varit suveränt framgångsrik i detta. Många av de sjukdomar som plågat människan och förkortat hennes liv har kunnat stävjas och botas genom reduktionistiska arbetssätt. Kartläggningen av människans gener är bara den senaste i en lång rad av framgångar. Men alla människans problem kan inte lösas genom att reduceras till sina minsta beståndsdelar. För det första kan inte reduktionismen förklara hur saker och ting blivit som de har blivit: varför har just de unika genuppsättningar som varje individ består av blivit just dessa och inte några andra av ett oändligt antal möjliga kombinationer? Vi måste nödvändigtvis erkänna slumpens roll. För det andra är det orimligt att tänka sig att ett reduktionistiskt arbetssätt skulle kunna ge svar på, till exempel, moraliska frågor om hur vi bör bete oss eller vad som är ett gott liv.

Det har ibland hävdats att bara humanvetarna betedde sig mera noggrant och systematiskt, mera som naturvetare, skulle de båda världarna kunna mötas och samhällsproblemen botas på samma sätt som kroppens sjukdomar kunnat botas. Edward $\mathrm{O}$. Wilson, från början myrexpert men sedan många år en av dessa få akademiker som försöker överblicka hela världens vetande, har med en drabbande blandning av metaforer sagt att vi drunknar i information samtidigt som vi svälter i brist på vishet. Från och med nu, skriver han 1998, kommer världen att styras av syntesskapare, sådana som kan ställa samman rätt information vid rätt tillfälle, tänka kritiskt kring det och fatta avgörande beslut på ett klokt sätt. ${ }^{124}$ Enligt Wilson är den ambitionen ett arv från upplysningen som det anstår oss att förvalta väl; de som fattar de kloka besluten måste ju behärska såväl naturvetenskapens som humanvetenskapens (olika) språk. Och så långt är det lätt att hålla med Wilson. Svårt blir det däremot när han hävdar i början av sitt stora verk Consilience. The Unity of Knowledge att "kulturens yttringar kommer till slut att falla ut som naturvetenskap" och i slutet, 300 sidor senare, att cellbiologens strategier också bör kunna användas för att förena naturvetenskapen med samhällsvetenskap och humaniora. Kan vi, med andra ord, bara förstå människans hjärna i tillräcklig detalj, kommer vi också att kunna förstå hennes tankar och handlingar. Skillnaden mellan naturvetenskapens och humanvetenskapens problem ligger inte i uppgiftens art utan i dess storlek, menar Wilson. ${ }^{125}$ Stephen Jay Gould ägnar en betydande del av sin bok

124 "We are drowning in information while starving for wisdom. The world henceforth will be run by synthesizers, people able to put together the right information at the right time, think critically about it, and make important choices wisely." (Wilson 1998, s300) Snart tjugo år senare kan man ännu inte se något tecken på att hans profetia infrias.

125 "I believe the enterprises of culture will eventually fall out into science" Wilson 1998, s10. "Thus the cell biologist looks inward and downward to ensembles of molecules and the cognitive psychologist to patterns of aggregate nerve cell activity... No compelling resaon has ever been offered why the same strategy should not work to unite the natural sciences with the social sciences and humanities. The difference between the two domains is in the magnitude of the problem, not the principles needed for its solution. The human condition is the most important frontier of the natural sciences." (Ibid s 298.) 
The Hedgehog, the Fox and the Magister's Pox, som jag flera gånger redan refererat till, åt att bemöta och vederlägga Wilsons idéer, eller åtminstone de delar som ser lösningen i en sammanfogning av humanvetenskap och naturvetenskap på naturvetenskapens villkor. Gould vill istället se framväxten av en ömsesidig kunskap om, och respekt för, varandras områden, "en sammanfogning som bygger på likvärdig aktning". Naturvetenskapen har en avgjord fördel, menar han, i att kunna etablera fakta medan humanvetenskapen har sin stora fördel i den överlägsna relevansen av de etiska frågorna, som är långt viktigare för människans liv än någon fråga naturvetenskapen någonsin kan ställa. ${ }^{126}$

\section{Humanvetenskapernas roller}

Den nya naturvetenskapen, grundad under 1600-talet, har tillsammans med sin praktiska följeslagare, teknologin, skördat oerhörda framgångar i att göra livet längre och bättre för stora delar av världens befolkning. Man kan dock vid samma naturvetenskapens dörr lägga ansvaret för massförstörelsevapen, miljöskövling och en svåröverblickbar klimatförändring. Naturvetarna själva har bara i undantagsfall kunnat ta ett ansvar för hur ny kunskap och nya upptäckter har använts. Användningen har skötts, eller misskötts, av folkvalda eller självutnämnda politiska ledare. I sitt föredrag om de två kulturerna argumenterade C.P.Snow, mot bakgrund av vad han själv uppfattade som naturvetenskapens triumf, för möjligheten att lyfta världen ur dess svält, fattigdom, träldom och elände. Bara det fanns flera som hade den rätta naturvetenskapliga och tekniska utbildningen att föra forskningen framåt, bara vi och framförallt våra ledare begrep det, skulle vi kunna bota alla världens sjukdomar, och utrota svält $i$ världen. Under de sextio åren som gått sedan Snow skrev har vi kommit en bra bit på väg mot det målet. Nu har i och för sig många övergett den grundläggande tanken här, att alla samhällen utvecklas längs samma bana och mot samma mål, nämligen Englands och USAs självskrivna överlägsenhet och att det är vetenskapliga upptäckter och ny teknologi som ska föra dem dit. Men inte alla. Skrapar man på ytan på politiker och ledarskribenter, forskare och folk i allmänhet finns nog den övertygelsen kvar. Inte minst fördelningen av forskningsmedel i världen är ett tecken på det. För mig i alla fall verkar det idag minst lika viktigt att förstå nationalism, religiös fundamentalism och internationell ekonomi som att förstå kärnklyvning och datasystem; ja, troligen viktigare, eftersom de förra utgör förutsättningarna för hur de senare ska användas och det är där som de moraliska övervägandena måste göras.

126 "a consilience of equal regard" "...science can claim a method capable of ascertaining factual truth, whereas ethical debate in the humanities cannot hope to attain the same kind of confidence about 'correct' answers. But we live in a world of trade-offs. Yes, science gains the virtue of factual validation. But even though ethical discourse must sacrifice such a summum bonum, who could deny that the basic duties of an ethical life are far more important to our meaning and being. So we swap certainty for salience." (Gould 2003, s 259.) 
Ett förenklat sätt att se på naturkunskapens respektive humanvetenskapens olika roller skulle kunna vara att naturvetenskapen förser oss med tillförlitlig kunskap om sakförhållanden medan humanvetenskaperna tolkar den och tillämpar den i samhällets och människans tjänst. Då blir det också rimligen humanvetenskaperna som ska ta initiativet när det gäller att föra ut akademins förståelser på den offentliga arenan. I så fall sköter sig naturvetarna betydligt bättre än humanvetarna för närvarande Och trots det beklagar sig humanvetarna som om det vore någon annans fel. I artikel efter artikel, bok efter bok beklagar sig företrädare för svensk humaniora över hur eländigt det är ställt. Humaniora får inga pengar och inget utrymme. Humaniora är i kris. Humaniora är satt på undantag. Humaniora missgynnas av en nationell forskningspolitik vars allt överskuggande mål är ekonomisk tillväxt och vars framgång mäts i citeringar och externa anslag. Utbildnings- och kursplaner upprättade efter Bologna-mallar lämnar ingen frihet för vare sig lärare eller student att följa ett bildningsspår. Och visst är det så; allt detta och lite till stämmer jag livligt in i, såsom framgår på åtskilliga andra håll i den här boken. Men i ansatsen finns en omisskännlig nostalgi, en längtan efter en tid då professorerna i historia och litteraturhistoria och konsthistoria var högt respekterade som sin tids smakdomare i samhällets högsta skikt. Då kunde man vandra genom de akademiska klosterlundarna utan att störas av vare sig självvärderingar eller rankningar, envisa studenters e-mail eller chefers senaste management-påhitt. Någon eller något har berövat oss humanister vår ställning och nu skulle vi vilja ha tillbaka den, tack, för akademins skull, för samhällets skull och för den mänskliga värdighetens skull.

Läget i USA är annorlunda. Även om humaniora är under attack även där, finns det fortfarande en stark och omfattande liberal arts-tradition i det amerikanska högskolesystemet där de flesta studenter förväntas genomgå en bred bildningsgång under de första två åren vid college. Man kan i och för sig invända att den svenska gymnasiets breda läroplan, som saknas i USA, uppfyller i stort sett samma funktion. Men i USA finns därmed också en undervisningsbas i högskolan som kan ge en viss stabilitet för humanistiska ämnen och deras lärarkår, inte minst förstås om det också stöds av stora donationer från förmögna alumner. Säga vad man vill om ett utbildningssystem som bygger på godtycklig välgörenhet, men sådana donationer ger onekligen den inte obetydliga delen av de amerikanske universiteten som har sådana tillgångar en frihet att stå utanför och ovanför den politiska dagsagendan. Därmed kan de bättre motstå samhällets växande krav på att högskolans utbildningar ska vara en motor i nationens ekonomiska tillväxt, och ingenting annat. Därmed blir inte heller det amerikanska systemet lika känsligt som det svenska för studenternas studiepreferenser. För studenterna påverkas naturligtvis minst lika mycket som politiker av ett idéklimat där ett bra jobb med en bra lön är inte bara det överskuggande målet, utan det enda målet.

Man kan knappast anklaga Martha Nussbaum, som jag flitigt hänvisade till under principen om handlingsförmågor, för att vara en självömkande humanist. I decennier har hon farit runt världen utifrån sina fixpunkter i USA och 
Indien, och talat högt och kraftfullt om nödvändigheten av en humanistisk utbildning för den demokratiska utvecklingen i världen. Hennes grundtes, till exempel i Not for Profit. Why Democracy Needs the Humanities från 2010, är att ett land behöver utbildningar som gagnar ekonomisk tillväxt, lika mycket som en individ behöver ett jobb som ger en dräglig inkomst. Men att rikta innehållet i en högskoleutbildning enbart och enkom mot de kortsiktiga, instrumentella färdigheterna för att skapa den tillväxten och de privatinkomsterna är förödande både för individen och för demokratin. Nussbaum menar i sin bok att man inte alls är tvungen att välja. Man kan göra båda delarna, både skapa grunden för en sund ekonomi och förbereda människor för att kunna ta sitt ansvar som självständiga medborgare. Den kreativitet och kritiska förmåga, de etiska grundvalar och globala samhällsinsikter som studier i humanvetenskaperna kan ge, gagnar både intäkterna och medborgarskapet. ${ }^{127}$ Detta är ett resonemang som jag återvänder till när jag pläderar för en akademisk yrkesutbildning. Nussbaum menar också att ett system som stödjer den enbart instrumentella yrkesutbildingen inte bara föraktar och utesluter humanistiska inslag för att de inkräktar på yrkesfärdigheternas utrymme; man är faktiskt också rädd för den inlevelse och empati som en humanistisk bildning odlar därför att en viss moralisk tröghet krävs hos folket om man ska kunna genomföra en ekonomisk politk som bygger på växande ojämlikhet och orättvisa i samhället. ${ }^{128}$

Nussbaums bok utgör en stark plädering för att alla studenter behöver någon form av bildningsgång som odlar kritisk självständighet och moralisk empati. Det är dock inte alldeles enkelt att se hur en sådan utveckling kulle kunna gå till $i$ ett svenskt sammanhang. Inte heller i ett engelskt, för den delen, där evangeliet om den instrumentella yrkesutbildningen farit fram om möjligt ännu starkare. Vi får nog erkänna att humaniora inte kommer att återerövra sin plats på den offentliga arenan genom att politiker och allmänhet plötsligt kommer till sans. Jag tror dock att det finns en god möjlighet att alltfler i samhället accepterar utbildningskonsekvenserna av att livet är mera än snöd vinning; att både människans och mänsklighetens stora problem inte kan övervinnas enbart genom teknologi och tillväxt; att det är de som tar sig an människan som individ och som samhällsvarelse som bör ta ansvar för forskningens frågor och prioriteringar, de som vågar se och beskriva de stora sammanhangen, som vågar slå fast normer och värden och dra hållbara konsekvenser av dem; att det är dessa som behöver tid och status och utrymme för att ställa dagordningen för utbildningen, forskningen och i förlängningen, politiken. Det

127 "... this economic interest too requires us to draw on the humanities and arts, in order to promote a climate of responsible and watchful stewardship and a culture of creative innovation. Thus we are not forced to choose between a form of education that promotes profit and a form of education that promotes good citizenship." (Nussbaum 2010, s 10.)

128 "But educators for economic growth will do more than ignore the arts. They will fear them. For a cultivated and developed sympathy is a particularly dangerous enemy of obtuseness and moral obtuseness is necessary to carry our programs of development that ignore equality." (Ibid, s 23.) 
kan knappast bara vara humanister. Men kloka och medietränade humanister och samhällsvetare måste i hög grad vara med. Och det måste vara humanister som inte väjer för naturvetenskapens och teknologins innehåll, frågor och perspektiv utan som kritiskt tillämpar dem i kraftfulla analyser och förslag. Det gör de idag. Det finns, vad jag kunnat se, långt färre humanvetare med naturvetenskapliga insikter eller med en överblick över tekniken för att till exempel trovärdigt kritisera en forskningsinriktning än det finns naturvetare, teknologer, medicinare som förmår själva sätta sina rön in i ett samhälleligt och mänskligt perspektiv som inte alls är givet och oproblematiskt. Det betyder att man erkänner och tar hänsyn till att världen omkring oss inte är entydig och given, fylld av sanningar och lagar som väntar på att vi ska upptäcka dem, utan är mångtydig och skapad av våra egna skiftande föreställningar om den och av våra egna konstruktioner av verkligheten.

\section{Visdomsforskning och vetenskaplig tvåspråkighet}

Det finns också en filosof i London, Nicholas Maxwell, som i många år hävdat att det är just upplysningen och konsekvenserna av att naturvetenskapens principer och metoder tillämpades på samhällsvetenskapen som har orsakat samhällets stora problem. Det var upplysningens förtjänst att förnuftet kunde börja styra samhället i stället för diktatoriskt godtycke, vidskepelse och en förtryckande kyrka. Men samtidigt, säger Maxwell, gjorde den goda tanken att samhällsvetenskaperna kunde ta över naturvetarnas metoder, att också den moraliska grunden försvann. Samhällsvetenskaperna kom därmed att samla kunskap om samhället, att iaktta objektivt men inte värdera. Genom att också samhällsvetenskaperna enligt Maxwell blir värderingsfria - och humaniora under de efterföljande århundraden gått samma väg - finns ingen i akademin som har till uppgift att undersöka vad en rätt och riktig väg framåt kan vara. Det är en tveksam slutsats med tanke på alla tydligt värdestyrda och flervetenskapliga forskningsområden och utbildningsprogram - postkoloniala studier, gender studies, fredsstudier och så vidare - men i sin grundtes, att akademins nuvarande kunskapsfokus istället bör omvandlas till en visdomsfokus, verkar ändå Maxwell vara något viktigt på spåren. ${ }^{129}$ Idag är huvuduppgiften för hela universitets- och forskningsvärlden att på bästa sätt samla fakta och information för att sedan använda den för att lösa samhällets uppgifter och problem. Maxwell menar att tågordningen måste bli tvärtom. Huvuduppgiften bör vara att i första hand söka visdom - klokhet kanske är en bättre översättning - där visdom ska förstås som förmågan att inse vad som är av värde för en själv och för andra. Vad är ett gott liv, vad är ett gott sätt att leva? Vilka mål, syften,

${ }^{129}$ Maxwells resonemang återges i koncentrerad form i hans artikel, "Creating a Better World. Towards the University of Wisdom" i Barnett 2012 och fylligare i hans From Knowledge to Wisdom (2007). 
ambitioner har vi med våra liv, både på personliga, institutionella och globala nivåer? Först när vi har klart för oss vilka mål vi har, ska fakta och information städslas för att bidra till att uppnå dem. Därmed blir det inte, till exempel, bara naturvetarnas sak att ställa frågorna för den naturvetenskapliga forskningen. Det är en uppgift för alla kloka tänkare och bör vara en huvuduppgift för akademin. Kunskapsinsamlingen i både naturvetenskaperna och humanvetenskaperna måste bli sekundär till att formulera och hitta lösningar till samhällets och människans stora hot. Splittringen mellan vetenskapliga discipliner förhindrar akademins möjlighet att påverka politiker eller allmänhet. Den vetenskapliga objektiviteten hindrar oss att uttala en uppfattning. Ingen - eller få - känner ett övergripande ansvar att föra samman disciplinerna i formuleringen och hanteringen av övergripande problem. Lösningen till detta, säger Maxwell, ligger i något han kallar visdomsforskning (wisdom inquiry). Detta innebär att vetenskaperna, och inte minst de naturvetenskapliga och tekniska vetenskaperna måste till sitt nuvarande fokus på teorier och evidens ett lägga främsta fokus på mål. Målen här är "att formulera individuella, globala och sociala livsproblem som måste lösas om livskvaliteten ska kunna förbättras"130. Om vi ska veta vad som är av värde i livet måste visdomsforskning också bygga på en undersökning och utveckling av våra livsfilosofier, något som är bannlyst från den traditionella kunskapsforskningen.

Maxwell ger ett antal goda exempel på mångdisciplinära centrumbildningar i England. Han kallar dem "de första antydningarna om en revolution". Sådana antydningar har funnits länge i Sverige också. Linköpings universitets temainstitutioner är kanske det främsta exemplet med Tema barn, Tema vatten o.s.v. De infördes 1980 och har lyckats genomföra en stor mängd mångdisciplinär forskning som är viktig för samhället, både nationellt och globalt. Men det svenska akademiska samhällets krav på indelning i silor för att en forskare ska kunna meritera sig och komma vidare i karriären tycks effektivt ha kvävt de flesta andra sådana mångvetenskapliga strukturer. De så kallade breddmagistrarna utgjorde också ett viktigt försök att länka flerdisciplinära studier på avancerad nivå till faktiska behov i samhället och på arbetsmarknaden. De har också avskaffats av disciplinernas stränga disciplin och försök att etablera flervetenskapliga huvudområden i Bolognaöverenskommelsens anda tycks gå samma öde till mötes, konfronterad av en rättlärig inomdisciplinär utvärderingsregim.

Återigen, vad kan göras? Jag är inte övertygad om att någonting alls kan göras; föreställningarna om två kulturer är nu så djupt inrotade att det troligen kommer att kräva en betydande världskris att rucka på dem. Men vad som bör göras kan man möjligen uttala sig om, och det är en del forskare som har gjort. Hans Larssons uppmaning att se helheten i delen är en ansats. Donald Campbells bön om att forskare systematiskt läser tidskrifter utanför det egna fiskfälllet en annan, Stephen Jay Goulds uppmaning till ömsesidig respekt och

130 "Articulate, and seek to improve the articualtion of, personal, social and global problems of living that need to be solved if the quality of human life is to be enhanced." (Maxwell 2012, s 6.) 
erkännande en tredje. Stefan Collini säger i sitt fylliga förord till en nyutgåva av Snows föredrag om de två kulturerna, att vad som behövs är inte att naturvetarna börjar läsa Dickens eller att humanister pluggar in några grundläggande naturlagar, utan snarare en slags vetenskaplig tvåspråkighet. Det innebär förmågan att inte bara använda fackspråket i vår egen specialitet utan också att uppmärksamma, lära av och kanske även bidra till ett bredare offentligt samtal. Och sådant arbete, föreslår han, bör betraktas inte bara som ett fritidsintresse eller välgörenhetsarbete utan ge ordentliga belöningar inom den egna disciplinen. ${ }^{131}$ Språkliknelsen använder han också när han talar om nödvändigheten av att utveckla och sprida ett offentligt språk där icke-kvantifierbara aspekter kan tilldelas sin tillbörliga vikt och betydelse. ${ }^{132}$ Detta är ett grundläggande problem som jag kommer att återvända till när det gäller målstyrning och kvalitetssystem: det är bara det som går att räkna som räknas. Förmodligen under inflytande av samma naturvetenskapliga metoddominans som har sina rötter i Descartes tvärsäkra kunskapsgrund och den dubbla bokföringen, är det bara det som kan uttryckas i siffror som ses som fakta, som en tillförlitlig bild av verkligheten.

Konsekvenserna av att naturvetenskap-humanvetenskap i så hög grad betraktas som ett motsatspar är alltså djupt besvärande men det är inte den enda dikotomi som ställer till besvär för akademins roller i världens utveckling. I min inledande diskussion om kunskap hävdade jag att teori och praktik aldrig kan stå i motsats till varandra utan utgör varandras nödvändiga komplement. Med denna insikt som grund går det att vidareutveckla en akademisk yrkesutbildning som både ger en bättre förberedelse för ett omväxlande yrkesliv och lämnar ett starkare bidrag till en lokal, regional och i förlängningen även en global utveckling

131 Snow 1998, s lvii f.

132 "the need to develop and diffuse a public language in which non-quantifiable considerations can be given their proper weight." Ibid s lxx f. 